\title{
SURGICAL CORRECTION AND HISTOLOGICAL ASSESSMENT OF LIPOMA IN DOG: A CASE REPORT
}

\author{
C. SAHA ${ }^{1}$, C. M. TARIF ${ }^{2}$, P. MUKHERJEE ${ }^{3 *}$, S. ROY ${ }^{3}$ AND S. MONDAL ${ }^{4}$ \\ ${ }^{1}$ Berhampore Veterinary Polyclinic (S.U.), Murshidabad- 742 101, West Bengal, India \\ ${ }^{2}$ Department of Veterinary Surgery and Radiology, West Bengal University of Animal and Fishery \\ Sciences, Kolkata-700 037, West Bengal, India \\ ${ }^{3}$ Department of Veterinary Clinical Complex, West Bengal University of Animal and Fishery Sciences, \\ Kolkata-700 037, West Bengal, India \\ ${ }^{4}$ Department of Veterinary Pathology, West Bengal University of Animal and Fishery Sciences, \\ Kolkata-700 037, West Bengal, India
}

\begin{abstract}
A two (02) years old male non-descriptive dog was presented with the history of progressively enlarging massive mass on the distal portion of the right hind limb. On physical examination the palpable mass was found semisolid type, but there was no pain at the affected site and no evidence of visible lameness. Lateral radiograph of right hind limb was advised and no attachment of the growth with the underlying bone was found on radiograph. Routine blood parameters were within the normal range and under general anaesthesia the mass was surgically removed. Excised mass was subjected to histopathological examination that revealed polyhedral closely packed neoplastic cells with vacuolated cytoplasm and flattened nuclei placed peripherally which confirmed the excised growth as lipoma. Present communication describes about the confirmatory diagnosis of lipoma and its uneventful surgical recovery in a dog.
\end{abstract}

Key words: Dog, Histopathology, Lipoma, Surgery

\section{INTRODUCTION}

Lipomas are benign fatty tumours of mesenchymal origin, comprisesed of mature fat cells (adipocytes), mostly seen in adult female or elderly obese dogs (Goldschmidt and Hendrick, 2002). Though exact etiology is unknown (Ludwig et al., 2017), the proposed factors are hereditary, hormonal, congenital and trauma (Rapidis, 1982). These are the most common soft tissue tumours, usually surrounded by a thin capsule (Hoseini et al., 2010) and may be localized in any region of the body, superficial or deep (Hakim et al., 1994). The growth of lipoma is gradual and painless in nature (Malik et al., 2020). Aiello (1998) reported that among domestic species, these neoplasms are common in dogs but occasionally found in cats and horses and rare in sheep, goat and pig (Pulley and Stannard, 1990). Lipomas can be differentiated from liposarcomas and infiltrative lipomas by histopathology, advanced imaging and surgical findings. Lipomas are mostly confined to their primary location (Kumar et al., 2017) and are less perilous compared to their malignant counterpart liposarcoma (Crowley et al., 2020). Approximately $16 \%$ of dogs suffer from lipomas (Randall et al., 1998). Šimkus et al. (2015) had reported high incidence of lipoma in female dogs (66.7\%) than male dogs $(33.3 \%)$ and incidence is higher in old aged

\footnotetext{
"Corresponding Author
} 
females (Julie et al., 2013), while O'Neill et al. (2018) also reported that the incidence of lipoma more in aged dogs. They may occur over the thorax, abdomen, thighs and proximal limbs and number of lipomas can be single or multiple (Cowell et al., 2008). The lipomas located between skin and muscle layers are generally soft on palpation and freely movable while intermuscular lipomas are not mobile as such (Veena et al., 2013). Most lipomas are small, well circumscribed, movable, but not painful. However, large lipoma mass may become a cause of worrying concern, as they can restrict feed intake and their presence in affected areas may cause pain to animal (Subapriya et al., 2020). Thus, the sizable lipomas can interfere with movement and locomotion, resulting in harmful consequences for the patients and anxiety for the owners. It has been reported that intr-regional injections of $10 \%$ calcium chloride solution cause lipoma regression, but this treatment is not recommended because irritation and skin necrosis may occur (Albers and Theilen, 1985). So the surgical excision is the right choice of treatment (Veena et al., 2013) lipomas usually do not recur following complete excision. Lipomas on microscopic examination may appear very similar to normal fat tissue, hence expertise and careful clinical examination of the mass is required to differentiate the benign lipomas from fatty change and normal fat tissue as well as the malignant fatty tumour i.e. liposarcoma (Subapriya et al., 2020). The histopathology remains the gold standard in the diagnosis of lipoma (Metgud and Kale, 2004). The present article describes the confirmatory diagnosis of lipoma, its surgical excision and uneventful recovery.

A two (02) years old male non-descriptive dog, weighing $14 \mathrm{~kg}$ was presented to OPD of Veterinary Clinical Complex, Faculty of Veterinary and Animal Sciences, West Bengal University of Animal and Fishery Sciences, Belgachia, Kolkata for assessment of large mass situated over distal part of right hind limb (Fig. 1A). Clinical history revealed that initially the mass was of small size and there was gradual increase in size over a period of 3 months. During clinical examinations, the dog was bright, comfortable with no signs of visible lameness, on palpation the growth appeared soft in consistency, located subcutaneously and moving freely. Lateral radiography of distal part of the right hind limb revealed absence of any attachment to the underlying bony structures (Fig. 1B). Haemato-biochemical parameters, liver function test parameters and the clinical parameters like heart rate, respiration rate, and body temperature were within physiological limits. From physical, clinical examinations and radiography the growth was confirmed as soft tissue tumour and planned to perform surgical excision.

The dog was pre-anaesthetised with inj. atropine sulphate@0.04 mg/kg body weight subcutaneously and inj.xylazine $\mathrm{HCl} @ 1.2$ $\mathrm{mg} / \mathrm{kg}$ body weight intramuscularly (Inj. Xylaxin ${ }^{\circledR}$ Indian Immunologicals Ltd., India) along with inj. ketamine $\mathrm{HCl} @ 5 \mathrm{mg} / \mathrm{kg}$ body weight intravenously (Inj. Aneket ${ }^{\circledR}$, Neon Laboratories Ltd., India) and inj. diazepam @ $0.5 \mathrm{mg} / \mathrm{kg}$ body weight as slow intravenous injection (Inj. Calmpose ${ }^{\circledR}$, Sun Pharmaceutical Industries Ltd., India) to achieve surgical anaesthesia. The dog was restrained in lateral recumbency and hairs of operative site were clipped off for aseptic preparation of surgical site. An elliptical skin incision was given as proposed by Boyer (2015) and following blunt dissection, the growth was exteriorized carefully by separating the capsule completely from the underlying tissues (Fig. 1C) and kept for histopathological examination. The haemostasis was achieved by ligation and electrocautery. After lavage, subcutaneous tissue was apposed with subcuticular sutures to obliterate anatomical dead space by chromic catgut number 1-0 as suture material. Skin incision was closed by non-absorbable 
Indian Journal of Animal Health, December, 2020

Lipoma in $\operatorname{dog}$

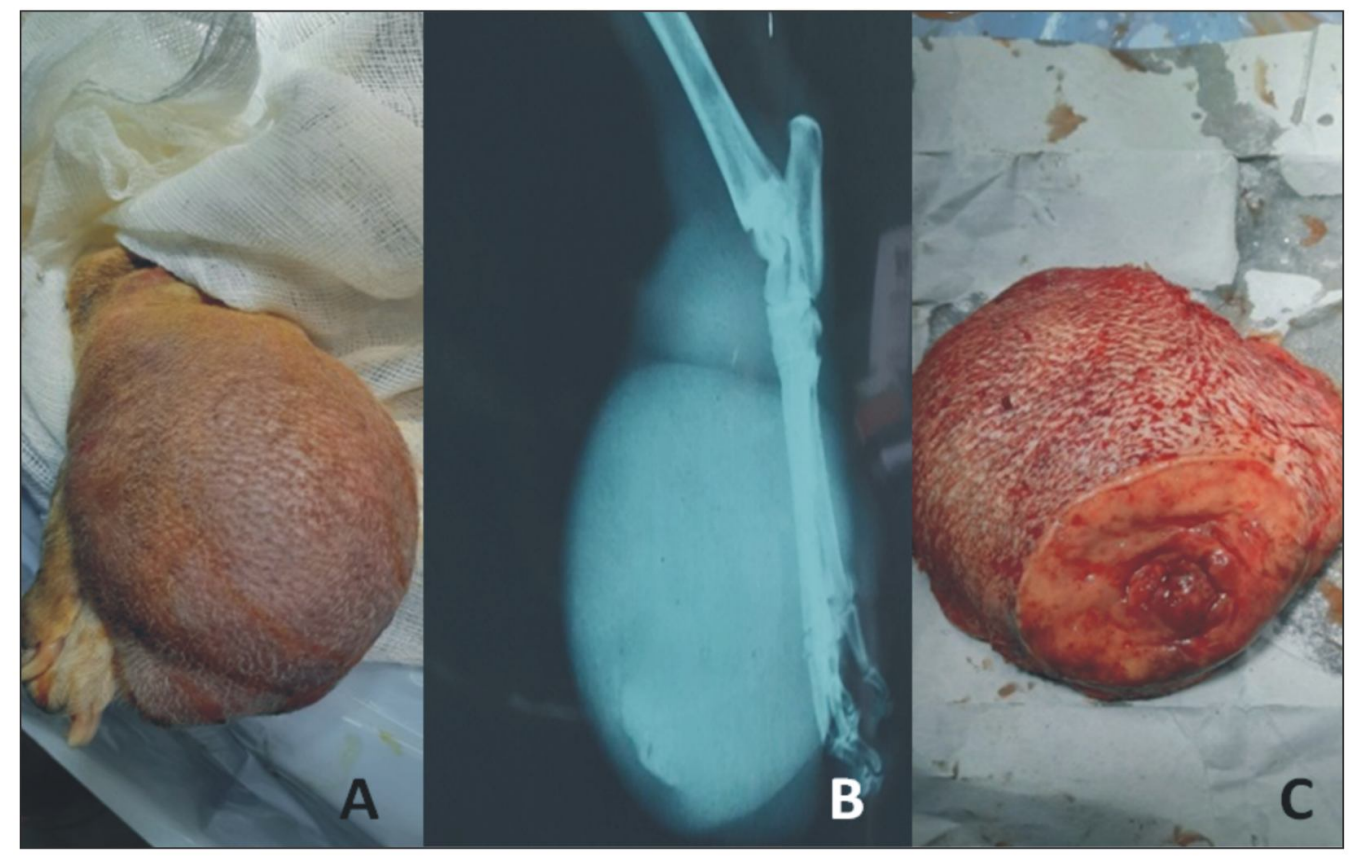

Fig. 1. Photograph showing soft mass at distal portion of hind limb. (A) the gross structure, (B) the radiograph showing no bony involvement and (C) the excised mass

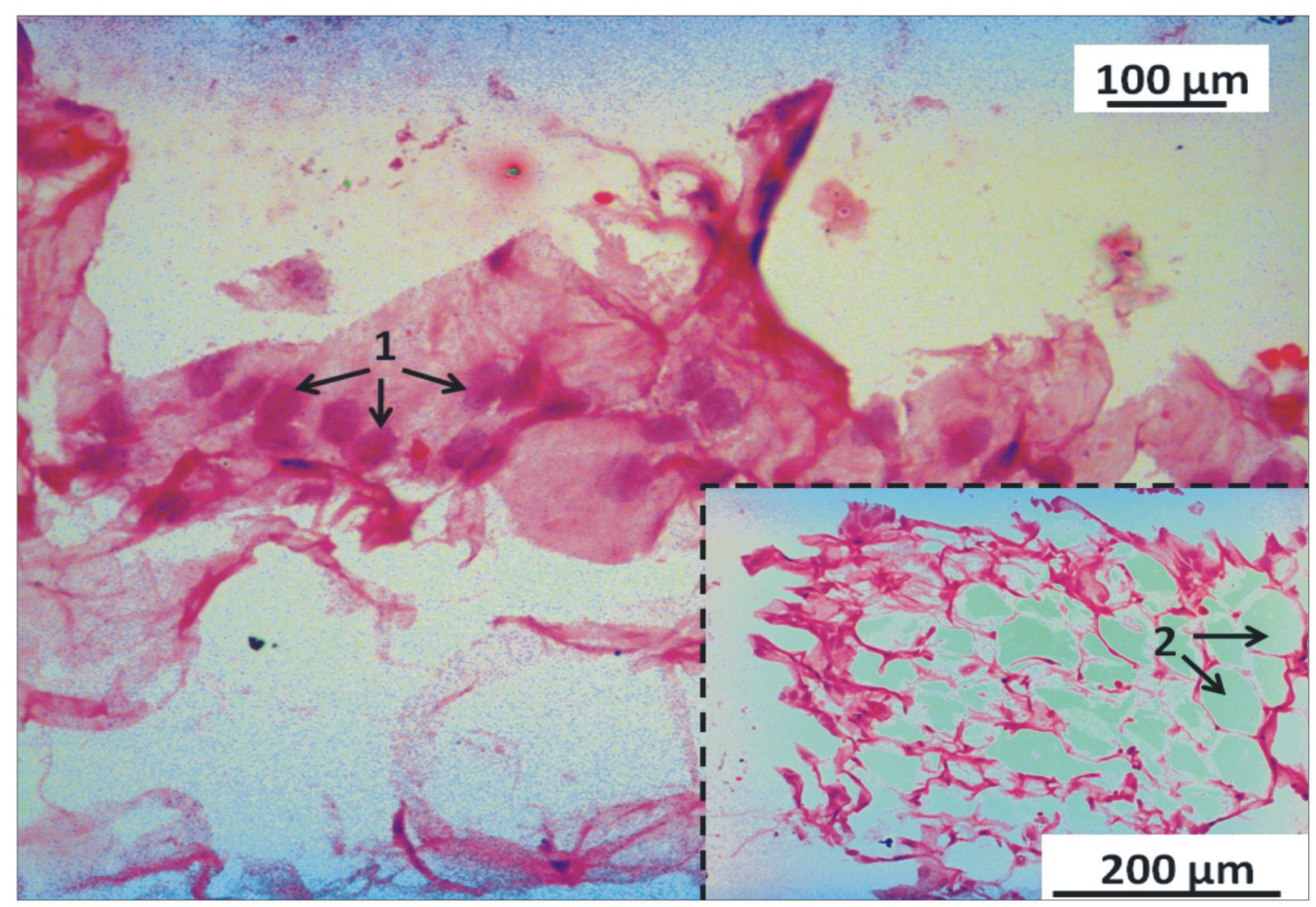

Fig. 2. Photomicrograph of histological section of lipoma in a dog showing polyhedral neoplastic cells containing fat globules with vacuolated cytoplasm and peripherally placed nuclei [1. Nuclei of Adipocytes, 2. White Adipocytes] [H \& E, 100X \& 200X] 
monofilament suture materials with simple interrupted suture pattern. As postoperative care, the animal was prescribed injection ceftriaxone sodium @25 mg/kg body weight intramuscularly (Inj. Monocef ${ }^{\circledR}$, Aristo Pharmaceuticals Pvt. Ltd., India) twice daily for 5 days, $5 \%$ DNS (250 $\mathrm{mL}$ b.i.d ) intravenously and inj. meloxicam @0.2mg/ kg body weight intramuscularly once daily (Inj. Melonex ${ }^{\circledR}$, Intas Pharmaceuticals Ltd., India) for 3 days. Restricted movement and every alternate day dressing with antimicrobial ointment (Mupirocin) were advised for next 10 days. The skin sutures were removed on $10^{\text {th }}$ day post operatively as the desired healing was achieved.

Cut section of the growth was evaluated for its external and internal appearance. The tumour sample was then sectioned and representative sample was fixed in $10 \%$ neutral buffered formalin for 48 hours, dehydrated in ascending grades of ethyl alcohol, cleared in xylene and then embedded in paraffin. Serial paraffin sections were cut at $5 \mu \mathrm{m}$ thickness and stained by routine Haematoxylin and Eosin.

On gross examination the tumour appeared as round, pendulous and semisolid type. Cut section of the tumour was oily and pale whitish in colour. Rajni (2005) also reported that lipomas appeared as round and soft masses and on section, the masses are greasy in consistency, pale whitish and shiny. The tissue material collected for histopathological screening floated in the formalin, which was again very well suggestive of lipoma (Subapriya et al., 2020). Histopathological examination of excised tumour growth revealed numerous polyhedral closely packed neoplastic cells containing white adipocytes with vacuolated cytoplasm. No mitotic figures were observed and the nuclei were found pushed to the periphery and appeared flattened against the cell membrane. Finally, lipoma was diagnosed (Fig. 2) based on the findings of Kosztyuova and Shim (2017).
Lipomas are called as universal tumours because of their distribution (Dehghani et al., 2019) and they are benign neoplasms that consist of localized nodules of fat and originate from adipocytes of the subcutaneous tissue. Mostly lipomas are located in a well-defined manner, facilitate surgical excision, and have a good prognosis. As previously stated, the lesion can arise in any part of the body where there is abundant adipose tissue (Lanng et al., 2004). Incidence of lipomas increases with the advancement of age and these lipomas are generally evident in overweight and old aged dogs (O'Neill et al., 2018). The proximal extremity of limb and trunk are the most common site for lipomas (Goldschmidt and Hendrick, 2002), but they may also appear in perineal region (Besalti et al., 2004), orbital region (Williams and Haggett, 2006) and inside body cavity (Mayhew and Brockman, 2002). Lipomas are more common than liposarcomas (malignant neoplasms of soft tissue) and histopathologically they are distinct (Baez et al., 2004). Surgical excision has low rate of complications and a good prognosis (Weiss and Goldblum, 2001). No postoperative complications were noticed during the observation period of 8 months after surgery and there was no recurrence of growth. The reason for non-recurrence in present case might be due to its complete surgical excision and early diagnosis as opined by Rao et al. (2011) and Kramek et al. (1985).

Lipoma appears to be a common clinical case in primary-care practice. Lipoma may not cause acute problems but as they become large, can interfere with normal function of body and often cause severe anxiety to the owners. Careful clinical, imaging, and histological examination can reveal the typical characteristic of lipoma. However, there is very little and scant information available in the published articles about exact causes of lipoma, the possible predisposing factors discussed in the present study. If complete surgical excision is achieved, recurrence is extremely rare. 


\section{REFERENCES}

Aiello SE, 1998. The Merck Veterinary Manual. Merck \& Co., Whitehouse station, NJ, pp702-703, doi: $10.1108 / 09504120610647492$

Albers GW and Theilen GH, 1985. Calcium chloride for treatment of subcutaneous lipoma in dogs. J Am Vet Med Assoc, 186(5): 492-494

Baez JL, Hendrick MJ, Shofer FS, Goldcamp C and Sorenmo KU, 2004. Liposarcomas in dogs: 56 cases (1989-2000). J Am Vet Med Assoc, 224: 887- 891, doi: 10.2460/javma.2004.224.887

Besalti O, Pekcan Z and Vural SA, 2004. Lipoma as a possible cause of perineal hernia in dog. Ind Vet J, 81: 1392-1393

Boyer M, 2015. A review of techniques and procedures for lipoma treatment. Clin Dermatol, 3(4): 105112, doi: 10.11138/CDERM/2015.3.4.105

Cowell RL, Tyler RD, Meinkoth JH and DeNicola DB, 2008. Diagnostic cytology and hematology of the dog and cat. $2^{\text {nd }}$ edn., Elsevier Health Sciences, pp20-51, doi: 10.1111/j.1939165X.2008.00058.x

Crowley J, Hosgood G, Crawford N and Richardson J, 2020. Computed tomographic findings, surgical management and postoperative outcomes of large intermuscular lipomas in the hind limb of 11 dogs. Aust Vet J, 98(4): 135-139, doi: 10.1111/ avj.12901

Dehghani N, Razmara F, Padeganeh T and Mahmoudi $\mathrm{X}, 2019$. Oral lipoma: case report and review of literature. Clin Case Rep, 7(4): 809-815, doi: 10.1002/ccr3.2099

Goldschmidt MH and Hendrick MJ, 2002. Tumors of the skin and soft tissues. In: Tumors of Domestic Animals. $4^{\text {th }}$ edn., DJ Meuten, edn., Iowa State Press, Iowa, pp45-117, doi: 10.1002/ 9780470376928.ch2

Hakim E, Kolander Y, Meller Y, Moses M and Sagi A, 1994. Gigantic lipomas. Plast Reconstr Surg, 94(2): 369-371, doi: 10.1097/00006534199408000-00025

Hoseini AT, Razavi SM and Khabazian A, 2010. Lipoma in oral mucosa: two case reports. Dent Res J (Isfahan), 7(1): 41-43
Julie B, Raghavan KS, Jayesh V, Swapna SA, Pradeep, MA et al., 2013. Surgical management of liposarcoma in a dog. Ind Vet J, 90: 97-99

Kosztyuova T and Shim TN, 2017. Rapidly enlarging lipoma. BMJ Case Rep, 17: bcr-2017-221272, doi: $10.1136 /$ bcr-2017-221272

Kramek BA, Spaceman CJ and Hayden DW, 1985. Infiltrative lipoma in three dogs. J Am Vet Med Assoc, 186(1): 81-82

Kumar PR, Prasad VD, Sailaja B, Sreenu M and Bose VSC, 2017. Surgical management of congenital lipoma in a calf. Res Rev J Vet Sci Technol, 6(2): 26-28, doi: 10.37591/rrjovst.v6i2.566

Lanng C, Eriksen BO and Hoffmann J, 2004. Lipoma of the breast: A diagnostic dilemma. The Breast, 13(5): 408-411, doi: 10.1016/ j.breast.2004.04.011

Ludwig EK, Byron CR, Lahmers KK and Santos MP, 2017. Frontal and caudal maxillary sinus lipoma in a horse. Can Vet J, 58(5): 503-507

Malik V, Singh A and Pandey RP, 2020. Surgical management of a deeply located retrobulbar lipoma in a buffalo. Buffalo Bull, 39(1): 103108.

Mayhew PD and Brockman DJ, 2002. Body cavity lipoma in six dogs. J Small Anim Pract, 43(4): 177-181, doi: $10.1111 / \mathrm{j} .1748-5827.2002$. tb00053.x

Metgud RS and Kale AD, 2004. Lipoma of the tongue. J Oral Maxillofac Pathol, 8(2): 96

O'Neill DG, Corah CH, Church DB, Brodbelt DC and Rutherford L, 2018. Lipoma in dogs under primary veterinary care in the UK: prevalence and breed associations. Canine Genet Epidemiol, 27(5): 9, doi: 10.1186/s40575-0180065-9

Pulley T and Stannard AA, 1990. Tumors of skin and soft tissue. In: Tumors in Domestic Animals (Pulley T and Stannard AA, edn), Univ California Press, Berkeley, pp23-87

Rajni FK, 2005. Cytological, histological and immunohistochemical evaluation of skin 
tumours in canines. M.V.Sc. Thesis submitted to Tamil Nadu Veterinary and Animal Science University, Chennai

Randall C, Fox T and Fox LE, 1998. Tumors of the skin and subcutis. In: Cancer in Dogs and Cats, Medical and Surgical Management (Wallace B M ed). Lippincott Williams \& Wilkins, Philadelphia, pp489-510

Rao CM, Prasad BC and Krishna NVVH, 2011. Surgical management of lipoma in a dog. Vet World, 4(1): 34

Rapidis AD, 1982. Lipoma of the oral cavity. Int J Oral Surg, 11(1): 30-35, doi: 10.1016/s03009785(82)80045-8

Šimkus D, Pockevičius A, Mačiulskis P, Šimkienė V and Zorgevica-Pockevič L, 2015.
Pathomorphological analysis of the most common canine skin and mammary tumours. Vet Med Zoot, 69 (91): 63-70

Subapriya S, Vairamuthu S, Pazhanivel N, George RS and Gokulakrishnan M, 2020. Cutaneous lipoma in dogs. J Entomol Zool Stud, 8(3): 17-19

Veena P, Bharathi S and Devarathnam J, 2013. Surgical management of lipoma in a dog. Intas Polivet, 14(2): 475-476

Weiss SW and Goldblum JR, 2001. Benign hipomatous tumours. In: Enzinger and Weiss's soft tissue tumors. $4^{\text {th }}$ edn, St. Louis, Mosby, pp571-639

Williams DL and Haggett E, 2006. Surgical removal of a canine orbital lipoma. J Small Anim Pract, 47(1): 35-37, doi: 10.1111/j.1748-5827. 2006.00010.x 